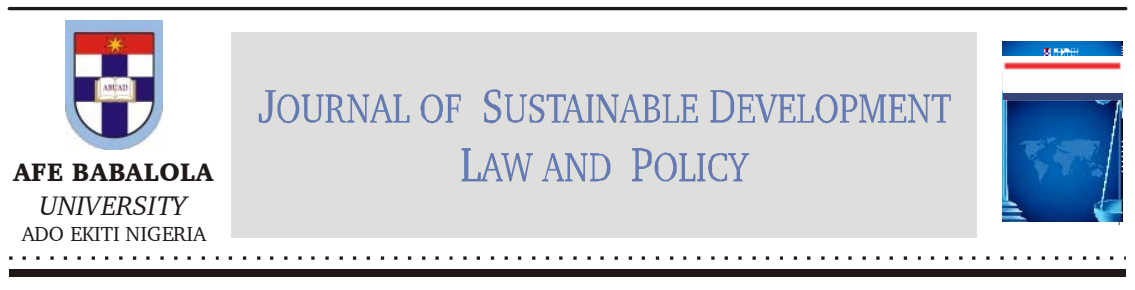

\title{
INTERROGATING THE MULTILATERAL TRADING SYSTEM AND PARADIGMS OF CORPORATE SOCIAL RESPONSIBILITY: IMPLICATIONS FOR NIGERIA
}

\author{
Laura Ani*
}

\begin{abstract}
Corporate social responsibility (CSR) norms are a strategic business policy that now forms the cornerstone of how international trade is governed globally. Although initially a voluntary initiative, its relevance in promoting social, environmental, and ethical responsibilities among global investors has arguably been conceived as trade distorting and violating the tenets of the World Trade Organization (WTO). Nonetheless, CSR is now mainstream in all related global transactions. This article seeks to evaluate the impacts of global CSR on international trade and examine the extent of Nigeria's participation in global CSR. The article argues that Nigeria should go beyond considerations of trade that focuses mainly on liberal market access and expand the practice to include environmental, social, and ethical practices. It concludes that adherence to international CSR will propel developing countries to meet the UN Sustainable Development Goals.
\end{abstract}

Keywords: Corporate Social Responsibility, World Trade Organization, Sustainable Development.

DOI: https://dx.doi.org/10.4314/jsdlp.v11i2.4

* LLB, LLM, M.Phil., Grad ICSAN. Research Fellow, Nigerian Institute of Advanced Legal Studies, Abuja. Email: ashleyani29@gmail.com 


\section{INTRODUCTION}

The terms corporate social responsibility (CSR), corporate strategic volunteerism, social marketing and strategic philanthropy have infiltrated mainstream literature and multilateral practices. ${ }^{1}$ CSR is now considered as the "social conscience of business success"2 and a firm's obligation to protect and improve social welfare. ${ }^{3}$ Its advocates argue that CSR principles might bring public relations benefits and signal the company, industry, or nation as desirable investment targets. ${ }^{4}$ However, others contend that CSR can increase business costs and invite criticisms of not living up to stated promises. ${ }^{5}$ Nevertheless, the benefits and costs of CSR to include communications about CSR has metamorphosed into an integral part of organizational marketing to enhance corporate image. ${ }^{6}$ Similarly, it has also rapidly grown in response to globalization with the civil society and the media focusing increasingly on the ethical, social and environmental aspects of business operations. ${ }^{7}$

Firms have also recognized that their conduct in purchasing and supply in international trade relations may have significant reputational and performance effects; hence the growing consensus about the correlation between CSR and overall corporate competitiveness. ${ }^{8}$ Consequently, this has led to growing commitments mostly by developed country multinational enterprise (MNEs) to align their practices with

1 Daniel Turban \& Daniel Greening, "Corporate Social Performance and Organizational Attractiveness to Prospective Employees" [1997] 40(3) Academy of Management Journal 658-672.

2 Dirk Matten and Jeremy Moon, "Implicit and Explicit CSR: A Conceptual Framework for a Comparative Understanding of Corporate Social Responsibility" [2008] 33(2) The Academy of Management Review 405

3 Chris Staeples, "What does Corporate Social Responsibility mean for Charitable Fund Raising in the UK?" [2004] 9(2) International Journal for Non-Profit \& Voluntary Sector Marketing 154-158.

4 Brayden King, "A Political Mediation Model of Corporate Response to Social Movement Activism." [2008] Administrative Science Quarterly 53(3) 395-421.

5 Jackie Smith, 'Power, Interests, and the United Nations Global Compact' in in T. Porter and K. Ronit (eds) Globalisation, Private Sector Authority, and New Modes of Democratic Policy Making' (New York: State University of New York Press, 2010).

6 Hardeep Chahal., \& R.D. Sharma, "Implications of Corporate Social Responsibility on Marketing performance: A Conceptual Framework" [2006] 6(1) Journal of Services Research, 205-216.

7 Roland Benabou \& Jean Tirole, J. "Individual and Corporate Social Responsibility" [2010] 77(305) Economica 1-19.

8 David Murillo \& Josep M. Lozano, "SMEs and CSR: An approach to CSR in Their Own Words" [2006] 67 Journal of Business Ethics, 227-240. 
globalized models of CSR frameworks where the CSR discussion has traditionally revolved and may be conceptualized as the "international drivers of CSR". 9

Conversely, CSR poses a great challenge to developing countries' aspirations of entering the global market, ${ }^{10}$ which may impair their opportunities to participate in export markets. For instance, the proliferation of CSR codes has created a corporate environment in which multinationals now ascribe significant weight to a range of social, environmental and ethical issues before solidifying business contracts and even require that these conditions be complied with otherwise the suppliers are required to exit the market if they fail to meet standards. It is now arguable that international trade is being subjected to the rudiments of CSR which not only ensures that certain standards are met but becomes very costly in terms of compliance, especially for the developing countries who are eager to participate in the global market.

Against this background, this article seeks to evaluate the impact of CSR on international trade, by examining whether an alliance between CSR initiatives and the World Trade Organization's (WTO) trade policies and agreements in international commerce can promote greater global CSR or constitute restrictive trade practices. If the latter holds, it will violate the basic rules and principles of the "multilateral trading system", taking into consideration that the General Agreements on Trade and Tariffs (GATT) is an offspring of neoliberal theory that underscore economic efficiency, comparative advantage and open trade. Secondly, the article examines the extent of Nigeria's participation in international trade through its commitments to global CSR. The analysis is achieved along the lines of two competing arguments of CSRs impacts on international trade. First, that global voluntary frameworks can place exogenous pressures on developing and emerging economies and CSR can be considered as anti-competitive or a restrictive trade practice. On the other hand, with increased international integration and trade, the responsibilities of firms evolve as its range of stakeholders expand. Thus, the need to comply with higher standards of CSR as firms become part of an integrated network in global trade.

9 Godwin L. Umoru, Corporate Citizenship in Law: Nigerian and Comparative Perspectives (Malthouse Press Limited, 2017). See also Philip Gugler and Jaclyn Y.J. Shi., "Corporate Social Responsibility for Developing Country Multinational Corporations: Lost War in Pertaining Global Competitiveness" [2009] 87 Journal of Business Ethics, 3-24.

10 Corporate Social Responsibility: Private Initiatives and Public Goals (OECD, 2001). 


\section{NATURE AND SCOPE OF THE CSR CONCEPT: A REVIEW OF THE LITERATURE}

The section is divided into three streams of literature, the first stream is a conceptual analysis that delineates firms' motivation to conduct CSR, drawing from various jurisdictions as CSR can differ across corporations' regions and countries. ${ }^{11}$ Although there is no universally accepted definition, some agreements do exist on the positive impact. ${ }^{12}$ The second stream of literature is the effect of CSR on investment performance, given that the relationship between investment strategies and CSR has become mainstream in international trade practices. The third stream is an analysis of the link between CSR and the WTO.

\subsection{Conceptual Analysis of CSR}

CSR is referred to as the "social conscience of business success." ${ }^{13}$ Eells and Walton aptly defined this when they said CSR refers:

to the problems that arise when a corporate enterprise casts its shadow on the social scene and the ethical principles that ought to govern the relationship between the corporation and society. ${ }^{14}$

In expanding the definition of CSR, Davis, Whitman and Zald define global CSR as a set of principles that hold firms responsible for actions far beyond their boundaries, including the actions of suppliers, distributors, alliance partners and even sovereign nations". ${ }^{15}$ Similarly,

11 Maignan Isabelle and David Ralston, “Corporate Social Responsibility in Europe and US: Insights from Businesses self-presentations" [2002] 33(2) Journal of International Business Studies 497-514.

12 Manuel C. Branco and Lucia L. Rodrigues, "Factors Influencing Social Responsibility Disclosure by Portugese-Companies" [2008] 83(4) Journal of Business Ethics 685-701.

13 Dirk Matten and Jeremy Moon, "Implicit and Explicit CSR: A Conceptual Framework for a Comparative Understanding of CSR" [2008] 33(2) The Academy of Management Review 405.

14 Richard S.F Eells, Clarence C. Walton and Richard D. Irwin Conceptual Foundations of Business (Homewood, IL., 1961) Cited in Salmi Mohd Isa, "Corporate Social Responsibility: What can we learn from the Stakeholders?" [2012] 65(3) Procedia - Social and Behavioural Sciences 329.

15 Davis, Gerald F., Marina V.N. Whitman, and Mayer N. Zald, "The Responsibility Paradox" Stanford Social Innovation Review [2008] Winter 31-37. 
Idowu postulates that CSR constitutes a significant departure from the shareholder primacy model and the business-as-usual approach and now embodies the conduct of the affairs of the entity with all its stakeholders, including the natural environment. ${ }^{16}$ Lim and Tsunmi, states that the reason for the shift in focus is that changes in the global normative environment have prompted many corporations to pledge commitment to CSR principles even though the progressive principles do not generate immediate or tangible benefits. ${ }^{17}$ Further, Welford posits that, "companies are beginning to realize that environmental issues need to be addressed for a number of reasons, including consumer pressure, potential savings, legislation and ethics". ${ }^{18}$ From Carroll's perspective, the author states that "for CSR to be accepted as legitimate, it has to address the entire spectrum of obligations businesses have to the society". ${ }^{19}$

These definitions and contexts resound well with the ISO 26000 guideline on social responsibility of organizations, it defines CSR as the:

... responsibility of an organization for the impacts of its decisions and activities on society and the environment, through transparent and ethical behavior that contributes to sustainable development, including health and welfare of society; takes into account expectations of stakeholders; is in compliance with applicable law and consistent with international norms of behavior; and is integrated throughout and practices in an organization's relationship. ${ }^{20}$

Conversely, contemporary research suggests that the general business environment i.e. political, economic, social and technological environment may impede or promote the development of CSR. ${ }^{21}$ Thus, CSR activities

16 Samuel I. Idowu, "The United Kingdom of Great Britain and Northern Ireland" in Samuel O. Idowu \& Walter Leal Filho (eds), Global Practices of Corporate Social Responsibility (Springer-Verlag Berlin Heidelberg 2009).

17 Lim Alwyn and Kiyoteru Tsutsui "Globalisation and Commitment in Corporate Social Responsibility: Cross-National Analysis of Institutional and PoliticalEconomy Effects" [2012] 77(1) American Sociological Association 69 -98.

18 Richard Welford, Corporate Environmental Management: Systems \& Strategies (Earthscan Publication Ltd, London 1998), p. 9.

19 Archie B. Carroll, "The Pyramid of Corporate Social Responsibility: Toward The Moral Management of Organizational Stakeholders" [1991] (July/August) Business Horizons 39-48.

20. See ISO guidelines on Social Responsibility. Available at < http://iso26000.info/ iso26000/> . Accessed. 14th March 2019.

21 Shaomin Li, Marc Fetscherin, Ilan Alon, Christoph Lattermann and Kuang Yeh, "Corporate Social Responsibility in Emerging Markets: The Importance of 
can be impeded by a lack of adaptation to the cultural contexts. ${ }^{22}$ For instance, Ewing and Windish observe that the application of Western CSR approaches may fail in the context of cultural differences. ${ }^{23}$ Similarly, Baughn et al further emphasize that CSR can be characterized not only by the cultural contexts, but also by the economic and political conditions. ${ }^{24}$ In the context of Nigeria, this was reiterated by Amaeshi et al where the authors state that CSR in Nigeria is "localized and socially embedded" and expected to address the socio-economic developmental challenges of the country e.g. poverty alleviation, healthcare provision, infrastructural development, education, among other things, and might not necessarily reflect the popular Western standard/expectation of CSR. ${ }^{25}$ Similarly, Ani suggests that CSR goes beyond voluntary assumptions of obligations and corporations should now respond to social expectations and be responsive to other constituents wealth to include environmental protection, labour, security and human rights. ${ }^{26}$

Barber and Allen envisage that contemporary discourse around CSR cover broader responsibilities than the purely social, where users of the nomenclature now least adopt the term "CSR" and rather refer to the term as "corporate responsibility" given the broad nature of the responsibilities of companies. ${ }^{27}$ Thus, beyond the baseline of good behaviour, organizations are to integrate compliance to laws and regulations, social, environmental, ethical, human rights and consumer concerns into the business strategies. ${ }^{28}$

Governance Environment". [2010] 50(5) Management International Review 635654.

22 Ibid.

23 Michael T. Ewing., \& Lydia E. Windish. "Contemporary Corporate Social Responsibility in China: An Extension of Confucian Philosophy?" Asian Business and Economics Research Unit Discussion Paper [No. 44], (Monash University 2007).

24 Baughn, C., Bodie, N., \& McIntosh, J. "Corporate Social and environmental responsibility in Asian Countries and other geographical regions" [2007] Corporate Social Responsibility and Environmental Management 14(4), 189 205.

25 Kenneth M. Amaeshi, Bongo C. Adi, Chris Ogbechie and Olufemi O. Amao, "Corporate Social Responsibility in Nigeria: Western Mimickry or Indigenous Influences?" [2007] (24) Journal of Corporate Citizenship 83-99.

26 Laura Ani. "Rethinking Corporate Social Responsibility in Nigeria" [2018] 9(1) The Gravitas Review of Business and Property Law 44-59.

27 Bernadette Barber B. and Barbara Allen. The ICSA Corporate Governance Handbook (4th Edition, ICSA Publishing Limited, 2017) p. 111.

28 Ibid. 


\subsection{CSR and Investment Performance}

An increasing number of countries have started to include CSR in their trade and investment agreements and now points to an increasing "legalization of the voluntary practice". ${ }^{29}$ Chapple and Moon suggest that a high level of inward foreign direct investments (FDI) into a country increases the likelihood that CSR practices will be adopted by domestic companies. ${ }^{30}$ Also, Newman argues that engaging with international customers, whether firms, final goods consumers or international suppliers, may encourage the transfer of other types of behaviour to domestic producers in the form of CSR. ${ }^{31}$

The United Nations Conference on Trade and Development (UNCTAD) indicates that CSR is now mainstream in global value chains and while it is a positive development that social and environmental issues are increasingly being integrated into global markets, concerns arise around the general lack of coherence between private CSR policies and purchasing policies and the insufficient assistance provided to SMEs in most developing countries to help them to meet the social and environmental conditions of their customers. ${ }^{32}$ Following the same arguments, Tencati opines that the impact of CSR initiatives on small and medium enterprises may create an unequal playing field considering that larger factories can adapt to CSR requirements, whereas suppliers, especially from developing continents, are likely to be excluded from the market for producing for companies that embrace CSR codes of conduct. ${ }^{33}$ Thus, suppliers will

29 ILO 2016, 'Corporate Social Responsibility in international trade and investment agreements: Implications for states, business and workers' (ILO Research Paper No.13) p. 9.

30 Wendy Chapple, \& Jeremy Moon, "Corporate social responsibility (CSR) in Asia: A seven-country study of CSR web site reporting" [2005] Business and Society 44(4) 415-441.

31 Carol Newman, John Rand, Finn Tarp and Neda Trifkovic, "The Transmission of Socially Responsible Behavior through International Trade" [2018] 101 European Economic Review 250-267.

32 UNCTAD, Corporate Social Responsibility in Global Value Chains: Evaluating and Monitoring challenges for small and medium sized suppliers in developing countries. <http://unctad.org/en/PublicationsLibrary/diaeed2012d3_en.pdf> Accessed 20th January 2019>.

33 Antonio Tencati, Angeloantonio Russo and Victoria Quaglia "Unintended Consequences of CSR: Protectionism and Collateral Damage in Global Supply Chains: The Case of Vietnam" [2008] 8(4) Corporate Governance 524. Cited in Christian Vidal- Leon "Corporate Social Responsibility, Human Rights and the 
have "less margin of manoeuvre". ${ }^{34}$

Gugler et al indicate that corporate CSR performance has become part of the criteria to access international financial markets, which has now manifested through the presence of MNEs through the establishment of FDI or more directly, through codes of conduct developed and imposed by individual buyers from developed countries. ${ }^{35}$ The authors resolve that CSR could impose potential market access barriers for exporters from developing countries and accentuate the power imbalance between large MNEs and small suppliers from developing countries. Therefore, developing-countries are in a less competitive position compared to their Western counterparts. ${ }^{36}$ Again, the authors refer to an unequal level playing field where MNEs from developed countries establish voluntary codes based on the general CSR principles and guidelines established by stakeholders from their home countries, while enterprises from developing countries, undergo exogenous pressures that might not match the standards they are used to complying with in their country. Flowing from these challenges, the United Nations Industrial Development Organization (UNIDO) has warned against the misuse of CSR schemes, noting that small and medium enterprises constitute 90 per cent of all businesses worldwide, many of which may be damaged by CSR demands that are "protectionist, culturally inappropriate or unreasonably bureaucratic". ${ }^{37}$

\subsection{The Link between CRS and the WTO}

The Geneva Social Observatory ${ }^{38}$ convened a panel discussion on how CSR and the WTO might ultimately evolve through a participatory dialogue. A key finding at the forum was that CSR in developing countries

World Trade Organization" [2013] 16 Journal of International Economic Law 893-920.

34 Ibid.

35 Philippe Gugler and Jacylyn YJ Shi, "Corporate Social Responsibility for Developing Country Multinational Corporations: Lost War in Pertaining Global Competitiveness?" [2009] 87(1) Journal of Business Ethics. 3-24.

36 Ibid.

37 UNIDO, "Corporate Social Responsibility for Market Integration. < http:// www.unido.org/what-we-do/trade-capacity-building/corporate-socialresponsibility-for-market-integration.html> . Accessed 20th January 2019.

38 See CSR and the WTO: Towards a Fairer Globalization or Misguided Virtue'? (Geneva Social Observatory conference)". Available at www.wto.org. Accessed 12th July 2020. 
has its unique challenges, particularly where legal regimes are deficient and this is not unconnected to the fact that CSR is business-led, which can particularly be onerous for public authorities of developing nations. ${ }^{39}$ However, some contenders were of the view that emphasis should be on promoting better coordinating mechanisms between the WTO and the UN's various specialized agencies, i.e. the International Labour Organization (ILO) and United Nations Environment Programme (UNEP)/ Convention on Biological Diversity (CBD) for more coherence..$^{40} \mathrm{~A}$ general consensus was delivered that CSR was never going to solve all the problems associated with poor governance and poverty. ${ }^{41}$

The WTO Ministerial Meeting in Hong Kong ${ }^{42}$ presented evidence that social and environmental compliance was becoming part of the global value chain agreements and that with trade and investment across borders comes increased responsibilities for governments as well as companies. It was further opined that companies who adhere to responsible business practices can gain comparative advantage in the global markets. ${ }^{43}$ Thus, companies can gain rewards from responsible practices and the result is that the market is willing to pay a premium for products and services that meet certain standards. ${ }^{44}$ However, it was also argued that responsible business standards can be a constraint to developing country export granting a comparative advantage to multinationals from developing countries. ${ }^{45}$

Also, Aaronson et al argue that the strict rules of liberal economic access may undermine the ability of the WTO Member States to promote human rights such as labour rights, access to food or equal access to public services. Thus, the WTO rules may, without intent undermine global corporate social responsibility and be a disincentive for firms to act responsibly. ${ }^{46}$ Similarly, arguments have developed that the WTO

39 Ibid.

40 Ibid.

41. Ibid.

42 Swedish Partnership for Global Responsibility. "Strengthening the Responsible Competitiveness of Countries and Companies in a Globalized World". (Side event during the WTO Ministerial Meeting in Hong Kong December 2005) Hosted by Thomas Ostros, Swedish Minister for Industry and Trade.

43 Ibid.

44 Ibid.

45 Ibid p. 4.

46 Susan A. Aaronson, S.A and Jamie M Zimmerman, Trade Imbalances: The Struggle to Weigh Human Rights in Trade Policymaking (Cambridge University Press, 2007); Cited in Susan A, Aaronson, A Match Made in Corporate and 
should add momentum to corporations to act responsibly as a marriage between CSR and trade could promote global standards in developing countries around the world. ${ }^{47}$

\section{GLOBAL CSR INITIATIVES}

The World Summit on Sustainable Development in Johannesburg in 2002 gave its backing to enhance corporate environmental, social responsibility and accountability. ${ }^{48}$ It includes actions at all levels to:

Encourage industry to improve social and environmental performance through voluntary initiatives, including environmental management systems, codes of conduct, certification and public reporting on environmental and social issues, taking into account such initiatives as the International Organizations for Standardization standards and Global Reporting Initiative guidelines on sustainability reporting, bearing in mind principle II of the Rio Declaration on Environment and Development. ${ }^{49}$

This is in line with principle 1 of the Rio Declaration which places emphasis on businesses to incorporate sustainable development into business practices and models, particularly through the development of Corporate Social Responsibility indicators, which monitor and evaluate business practices. ${ }^{50}$ This is similar to the OECD Guidelines for Multinational Enterprises which creates parameters for them to implement its due diligence recommendations for responsible business conduct by sector to include the agricultural supply chains, extractive sector stakeholder engagement, financial sector due diligence, mineral supply chains and textile and garment supply chains. ${ }^{51}$ More recently, the United

Public Interest: Marrying Voluntary CSR Initiatives and the WTO. [2007] 41(3) Journal of World Trade, 629-659.

47 Susan A. Aaaronson S.A. 'A Match Made in Corporate and Public Interest: Marrying Voluntary CSR Initiatives and the WTO. Ibid, p. 630.

48 See United Nations Report of the World Summit on Sustainable Development, Johannesburg, (South Africa, 26 August 4 September 2002), 18.

49 Ibid.

50 See Review of Implementation of the Rio Principles, prepared by the stakeholder Forum for a Sustainable Future (December 2011), p. 11.

51 See OECD Guidelines for multinational enterprises. < https://www.oecd.org/ corporate/mne/> Accessed 23rd December 2019. 
Nations Guiding principles on Business and Human Rights provides for corporate responsibility to respect human rights. ${ }^{52}$ Similar initiatives are the International Labour Organization's (ILO) Declaration of Principles and Rights at Work and tripartite Declaration of Principles concerning Multinational Enterprises and the UN Global Compact. Thus, the responsibility of business enterprises to respect human rights applies to all enterprises regardless of their size, sector, operational context, ownership, and structure. ${ }^{53}$

There is now a societal expectation that organizations not only have a responsibility towards social and environmental welfare but should play a positive and integral role in achieving it. Thus, the 17 United Nations Sustainable Development Goals (UNSDGs) and the 169 targets adopted in 2015 are a set of aspirational goals to end poverty, protect the planet and ensure prosperity for all, as part of the United Nations 2030 Agenda for Sustainable Development. Many of these initiatives, although not exhaustive, are employed to motivate organizations to adopt social responsibility to meet the SDGs by 2030 .

Global CSR practices are based on ethical values, adherence to stakeholders, i.e., employees, communities, and environmental standards. Similarly, globalization has allowed MNEs to find lucrative business ventures in environments where adherence to standards are non-existent. However, the alleged crimes (for example, oil spills in the Niger Delta in Nigeria and human rights abuses, among other things) committed by these MNEs have not gone unnoticed by civil society organizations. A 2004 study of 1,000 consumers conducted by the US Chamber of Commerce in 30 countries found that 30 US companies in particular are seen as exploitative, inhumane, and arrogant. ${ }^{54}$ Similarly, a 2004 poll by Industry Canada found that global companies are among the least trusted institutions of the countries surveyed particularly in Europe, Latin America and Eurasia. ${ }^{55}$ In response, several companies have embraced CSR

52 See United Nations Guiding Principle on Business and Human Rights: Implementing the United Nations "Protect, Respect ad Remedy" Framework (2011) 13-26.

53 Ibid.

54 US Chamber of Commerce, "The Corporate Citizen", Interview with Keith Reinhard, President, business for Diplomatic Action, Ic. Chairman, DDB Worldwide (August - September 2004), <http://www.uschamber.com/ccc/ news/2004/aug-sep/0409feature.htm>. Accessed 3 April 2019.

55 See Industry Canada <http://strategis.ic.gc.ca/epic/internet/incsr-rse.nsf/en/ rs00123e.html>.Accessed 3 April 2019. 
initiatives in order to correct these abuses.

It is questionable whether the motives to adopt CSR initiatives by MNEs are subscribed to as matter of ethical motives or a screen to avoid corporate scandals that can adversely affect a company's reputation and profitability. Antagonists to the global system theory have argued that global CSR is a case of "organized hypocrisy", in which developed countries make extensive commitments to CSR without any intention of binding these commitments. ${ }^{56}$ Conversely, what prevails in developing countries is "decoupling" 57 where commitments are largely mimetic by reason of their lack of resources to align their practices with global models. ${ }^{58}$

There is no internationally accepted approach to CSR. Hence, companies chose to adopt one of several CSR initiatives or voluntary schemes depending on the nature of their business, customers, or supply chain. Firms from importing countries endorse several parameters, including human rights, as well as environmental and labour standards which must be adhered to by suppliers to sustain continuous business relations. There are two primary means by which MNEs incorporate CSR into their operations: (i) Written codes of conduct; and (ii) Disclosure and reporting. Companies adopt one or a combination of these CSR strategies. ${ }^{59}$

\subsection{Codes of Conduct}

The demand for socially responsible operations and monitoring of these

56 Stephen D. Krasner, Soverignty: Organised Hypocrisy. (Princeton University Press,.1998) Cited in Alwyn Lim and Kiyoteru Tsutsi "Globalization and Commitment in Corporate Social Responsibility: Cross-National Analysis of Institutional and Political-Economy Effects". [2012] 77(1) American Sociological Review 69-98.

57 Alwyn Lim and Kiyoteru Tsutsi "Globalization and Commitment in Corporate Social Responsibility: Cross-National Analysis of Institutional and PoliticalEconomy Effects" [2012] 77 American Sociological Review 69-98.

58 John W. Meyer, John Boli, George M. Thomas and Francisco O. Ramirez 'World Society and the Nation-State" [1997] 103 American Journal of Sociology 14481.

59 Efforts to institutionalize global CSR norms date to the early 1970's. For instance, the United Nations (UN) established the Center on Transnational Corporations in 1974, the Organization for Economic Cooperation and Development (OECD) adopted its guidelines for Multinational Enterprises in 1976; and the International Labour Organization (ILO) adopted the Tripartite Declaration of Principles Concerning Multinational Enterprises and Social Policy in 1977. 
operations are mostly channelled through organizations other than states, and the emphasis favours high proportion of self-regulation. ${ }^{60}$ Buyers are increasingly using codes and external certification schemes developed by the ISO26000, Global Reporting Initiatives (GRI) and United Nations Global Compact (UNGC) among others, which are referred to as the Multi-stakeholder Initiatives (MSI) ${ }^{61}$ and the Business Associations (BA) carried out through industry associations. ${ }^{62}$ MSIs have been established to set standards in almost every major global industry, ranging from certifying the production of clothing and food, through to monitoring the extraction of oil and gas, or to establishing codes of conduct for internet companies regarding privacy and freedom of expression. ${ }^{63}$ These bodies come together and agree on a code of conduct which may be industry-specific or cross industries that commonly build up a monitoring and certification programme which companies use to demonstrate that their supplier factories are operating within the performance standard outlined by the MSI. ${ }^{64}$ Examples of codes and certification strategies are the Fair Labour Association (FLA), the Business Social Compliance Initiative (BSCI), Ethical Trading Initiative (ETI), Pharmaceutical Industry Principles for Responsible Supply Chain Management, Ethical Trade Initiatives (ETI), Better Cotton Initiative (BCI) to include Fair Trade Certification schemes such as Social and Eco-labelling standards, and so on. These schemes are sector specific and differ considerably in application, some with higher level of requirements than others.

For instance, apparel retailers have only accredited its sourcing factories from China and Turkey to the FLA and apparel, accessories and luxury goods industries subscribe to the BCI (For instance Gap and Nike) and Consumers International. ${ }^{65}$ Similarly, Social and Eco-Labelling schemes, go beyond the characteristic of the product but extend to incorporate production and trading processes (these would include labour

60 Kerstin Sahlin Anderson "Corporate Social Responsibility: A trend and a movement, But of What and for What?" [2006] 6(5) The International Journal of Business in Society, 595-608.

61 Kanji Tanimoto "Do Multi Stakeholder Initiatives Make for Better CSR? [2019] Journal of Business Society< https://doi.org/10.1108/CG-08-2018-0267> Accessed 15 May 2019.

62 Ibid.

63 See Multi-Stakeholder Initiatives and Responsible Business Conduct (Background note) Available at https://mneguidelines.oecd.org.

64 Ibid.

65 See Aaaranson et al. (n. 47). 
standards and the processes under which the products where produced). These initiatives guarantee suppliers with higher prices than the market price. Suppliers gain a competitive advantage and consumers are willing to pay a premium on these goods and are guaranteed the process in which goods and services are produced, delivered, and marketed. International bodies such as the Fair-Trade Labelling Organizations International ${ }^{66}$ and the Forest Stewardship Council exist to regulate and certify the labelling criteria. ${ }^{67}$ However, producers in developing countries find it difficult and expensive to invest in creating environmentally sustainable production conditions and find that eco-labelling are monopolistic. ${ }^{68}$

\subsection{Disclosure and Reporting}

The most widely endorsed global CSR framework is the United Nations Global Compact (GC) and is the world's largest corporate social responsibility initiative. The GC requires participating companies to produce an annual Communication on Progress (COP) that details their work to embed the 10 core principles into their strategies and operation, including efforts to support societal priorities. ${ }^{69}$ The GC has 13,558 corporations of different industry backgrounds and sizes worldwide. Among these are 17 Nigerian companies comprising SMEs, NGOS, financial and telecommunications institutions. However, a few of the Nigerian companies that signed the compact are not complying fully with reporting requirements. They only make baseline ceremonial commitments and no submission of COPs. ${ }^{70}$ The GC relies heavily on self-reporting by companies and since only voluntary monitoring by civil society organizations is done, companies turn the monitoring or certification process to a rubber stamp for covering up their socially irresponsible practices.

66 See Fair Trade International < https://www.fairtrade.net> Accessed 14 April 2019.

67 See Forest Stewardship Council <https://fsc.org > Accessed 14 April 2019.

68 Aaaranson et al (n. 47).

69 The 10 core principles are subsumed under Human Rights, Labour, Environment, and Anti-Corruption. See the UN Global Compact https:// www.ungloalcompact.org/what-is-gc/missions/principles Accessed 20 March 2019.

70 See the UN Global Compact. <https://www.unglobalcompact.org/what-is-gc/ participants? page $=6>$ Accessed 20 March 2019 . 
The United Nations Global Reporting Initiative (GRI) is a sharp contrast to the ceremonial commitment of the GC. The GRI requires more substantive commitment; hence it focuses on the dissemination of sustainability reporting guidelines for corporations to voluntary disclose their economic, environmental, and social activities. The GRI guidelines are considerably more rigorous compared to the simple endorsements of the GC and is presented with structured and qualitative information. Thus, the GRI requires a substantial commitment to disclose their CSR practices.

A recent UNCTAD study reveals that CSR is the new business landscape facing small and medium enterprises in developing countries, and many challenges exist in implementing it. Thus equipping SMEs to address CSR issues has become an important policy objective of enterprise development. ${ }^{71}$ The multiplication of CSR schemes has resulted in a maze of standards, customs, rules, procedures, and principles that suppliers must endorse and implement. To this end suppliers will need to incur substantial investment in bringing their internal structures to conform to these norms with human rights standards in combination with verification and monitoring mechanisms prescribed by each code. ${ }^{72}$ For instance if a supplier produces for several companies, it will necessitate adjusting its production methods to the demands of each of its client CSR codes of conduct. ${ }^{73}$ Thus, it has become evident that a disparate collection of national and or industry-level frameworks is not sufficient to address global CSR challenges. ${ }^{74}$ There is a widespread diffusion of global CSR with an uneven implementation across the globe. ${ }^{75}$

71 See Corporate Social Responsibility in Global Chains, (Geneva: UNCTAD, 2012) <http://unctad.org/en/PublicationsLibrary/diadeed2012d3_en.pdf > Accessed 20 March 2019.

72 Laurence E. Harribey, "Strategic Value of Corporate citizenship" in Samuel O. Idowu and Cline Louche (eds), Theory and Practice of Corporate Social Responsibility (New York: Springer, 2011).

73 Christian Vidal- Leon "Corporate Social Responsibility, Human Rights and the World Trade Organization" [2013] 16 Journal of International Economic Law 893-920.

74 Ruggie G. John, "Taking Embedded Liberalism Global: The Corporate Connection" in David Held and M. Mathias K. Archibugi (eds) Taming Globalization: Frontiers of Governance, (Cambridge Polity Press, 2003)

75 Alwyn Lim and Kiyoteru Tsutsi "Globalization and Commitment in Corporate Social Responsibility: Cross-National Analysis of Institutional and PoliticalEconomy Effects" [2012] 77(1) American Sociological Review, 69-98. 
Consequently, SMEs are faced with implementation challenges and "auditing fatigue". ${ }^{76}$

In addition, a consequence of not complying with CSR requirements may take the form of corrective and, in extreme cases, punitive measures. For instance, when the violation of a code is recurrent, the purchasing firm may whenever it deems appropriate halt productions or cancel contracts or terminate the business relationship with the non-conforming supplier. ${ }^{77}$

\section{AN OVERVIEW OF THE WTO TRADING SYSTEM}

The preamble to the WTO states that:

all countries, including the poorest, have assets - human, industrial, natural, financial - which they can employ to produce goods and services for their domestic markets or to compete overseas. ${ }^{78}$

To integrate successfully into the global economy, developing countries can benefit from the "comparative advantage" principle which assists countries to prosper by taking advantage of their best domestic products which they trade for the best from other countries. Trade liberalization should positively eliminate poverty and insulate shocks in the domestic economy and eliminate government-imposed restrictions on transnational movement of goods, capital, and people through liberal economic policies. Consequently, many countries can take advantage of global markets to increase their GDP.

The amount of trade worldwide has increased sharply in relation to GDP and output, ${ }^{79}$ this development is often attributed to the efforts made by the General Agreement on Tariffs and Trade (GATT) which, became the WTO in 1995. The main purpose of GATT/WTO is to lower barriers to trade, and this is considered to have had a profound influence on international trade. The GATT/WTO is one of the multilateral agreements and an international treaty binding on all WTO Members.

76 UNCTAD (n 32).

77 Ibid.

78. WTO Secretariat, Trading into the Future (1998, 2nd edition), 8-9. Cited in Peter Van Bossche The Law and Policy of the World Trade Organization. Text, Cases and Materials (Cambridge University Press, 2006).

79 Daniel Hummels. "Transportation Costs and International Trade in the Second Era of Globalization" [2007] 21(3) Journal of Economic Perspectives, 131-154. 
The principles of non-discrimination are two-faceted: it consists of the "most-favoured nation (MFN) treatment obligation" and the "national treatment obligation". These notions form the cornerstone of the WTO "multilateral trading system" to ensure fair and predictable international trading relations and equality of opportunity to import from or to export to all WTO Members. WTO members are not allowed to discriminate between its trading partners by, for example, giving the products imported from some countries more favourable treatment with respect to market access than the treatment it accords to the products of other members..$^{80}$ In simple terms, the MFN treatment obligation prohibits a country from discriminating between products originating in or destined for different countries; ${ }^{81}$ while the national treatment obligation prohibits a country from discriminating against imported products once the imported products have entered the domestic market. ${ }^{82}$

Article I, GATT 1994 provides that:

With respect to customs duties and charges of any kind imposed on or in connection with importation or exportation or imposed on the international transfer of payments for imports or exports and with respect to the method of levying such duties and charges, and with respect to all rules and formalities in connection with importation and exportation, and with respect to all matters referred to in paragraphs 2 and 4 of Article III, any advantage, favour, privilege or immunity granted by any [Member] to any product originating in or destined for any other country shall be accorded immediately and unconditionally to the like product originating in or destined for the territories of other [Members].

The GATT 1994 is only concerned with liberalizing trade in goods through the reduction of tariffs and other trade barriers and eliminating discrimination as indicated above. Thus, these principles may limit how and when governments can link CSR codes of conduct to trade agreements. The WTO only regulates the behaviour of governments, not businesses in international trade. It is more concerned with relationships between States. The GATT/WTO is not concerned with how a State treats

80 Articles I.1 \& II.1 GATT 1994.

81 Ibid.

82 Article III, GATT 1994. 
its own citizens, but rather how it treats non-citizens who seek to trade. ${ }^{83}$

\subsection{Beyond the WTO}

Many kinds of restrictions and prohibitions imposed by states for reasons of health, safety, environment and public morals may result in restraints on imports that could be regarded as inconsistent with GATT, particularly article XI which provides for the general elimination of quantitative restrictions. These emerging protectionist measures sometimes voluntarily imposed by private businesses can discourage producers from developing countries from participating in world trade due to stricter standards adopted by a colosseum of major importing countries or private entities. Thus, these initiatives are developing a new shift of translating CSR codes of conduct into international trade law. Generally, CSR codes of conduct are implemented and adopted by private stakeholders; hence they are not a requirement of governments. ${ }^{84}$

The case before the GATT panel in 1991 known as the Tuna Dolphin I case was clearly illustrative of the imposition of environmental regulations over the requirements of the WTO affirmative obligations. The Panel concluded that the prohibition of imports by the United States of certain Yellowfin tuna from Mexico and several other countries on the grounds that they had not met the comparability requirement of the US law pursuant to the Marine Mammal Protection Act was contrary to Article $\mathrm{XI}(1)$ of the GATT and unjustified by Article XX(b) and XX(g). The key issues raised by the GATT panel was whether trade rules permitted actions to be taken against the method used to produce goods rather than the quality of the goods themselves. This case became known as the "product versus process issue".

The facts of the case are rather simple in contextualizing the CSR and WTO dilemma. The harvesting of tuna required the use of purse sine nets, ${ }^{85}$ but in the tuna-fishing process, dolphins are frequently found

83 Steve Charnovitz, "The Globalization of Economic Human Rights" [1999] Brooklyn Journal of International Law < http://www.geocities.com/charnovitz/ Brookly.htm > Accessed 5 October 2019.

84 United States - Restriction on Imports of Tuna (Mexico v US) (Tuna/Dolphin I), GATT Doc DS21/R (3 Sep 1991), Official D3ocuments issued under the GATT are now available on the WTO Website, at <http://www.wto.org/english/ tratop-e/envir-e/edis04-e.htm > . Accessed 5 October 2019.

85 Purse sine nets are used in the ocean to target dense schools of fish like tuna and mackerel. See Marine Stewardship Council. Available https:// www.msc.org/what-we-are-doing/our-approach/fishing-methods-and-geartypes/purse-seine Assessed 9 July 2020. 
swimming above the tuna; hence they are fatally wounded in the process of being caught in the nets. Dolphins are considered endangered and adored species. Because of this, the US government placed an embargo on imports of tuna from Mexico, Venezuela, Panama, Ecuador, and the tiny pacific island of Vanuatu in 1990 on the ground that they did not have a conservation programme designed to protect dolphins. Mexico initiated a dispute proceeding under Article XXIII of the GATT ${ }^{86}$ and contended that the US restrictions on imports violated Article XI(I) of the GATT. In turn, the United States raised the defence of Article XX (a) \& (g) ("General Exceptions" for non-economic values).

Article XI(I) provides that:

No prohibitions or restrictions other than duties, taxes or other charges, whether made effective through quotas, import or export licenses or other measures, shall be instituted or maintained by any contracting party on the importation" of any product of the territory of any other contracting party or on the exportation or sale for export of any product destined for the territory of any other contracting party.

Article XX(a) \& (b) provides that:

... "arbitrary or unjustifiable discrimination between countries ... or a disguised restriction on international trade, nothing in this Agreement shall be construed to prevent the adoption or enforcement by any contracting party of measures... (b) necessary to protect human, animal or plant life or health; ...(g) relating to the conservation of exhaustible natural resources if such measures are made effective in conjunction with restrictions on domestic production or consumption."

To invoke and justify the exceptions under Article XX, the panel in US - Gasoline, provided a two-tier test to establish the defence of Article $\mathrm{XX}$; (a) the requirements of one of the exceptions listed in paragraph (a) to (j) of Article XX; and (ii) the requirements of the chapeau of Article $\mathrm{XX}$ (to prevent "arbitrary or unjustifiable discrimination between countries" or a "disguised restriction on international trade"). ${ }^{87}$ The vital

86 The GATT 1994 contains "consultation and dispute settlement provisions" in both Articles XXII and XXIII. Article XXIII: 1(a)-(c) sets out the specific circumstances in which a WTO Member is entitled to a remedy.

87 The appellate body in US - Shrimp stated that ... "the chapeau embodies the recognition on the part of the WTO Members of the need to maintain a balance 
phrase in Article XX is that the agreement shall not prevent any Member country from adopting or enforcing measures even if they are inconsistent with the GATT 1994. These exceptions under Article XX are conditional, in that they only provide for justification of an otherwise illegal measure when the conditions of the two-tier test are met. However, the panel in Tuna/Dolphin I held that Article XX could not justify measures that undermine the WTO multilateral trading system and that a measure of a Member "conditioning access to its market for a given product upon the adoption by the exporting Member of certain policies would undermine the multilateral trading system.

A second complaint known as the Tuna/Dolphin $\mathrm{II},{ }^{88}$ was brought by the European Community and the Netherlands challenging the same regulations as in Tuna/Dolphin I. This time the complaining parties focused on the provision in the United States statute prohibiting imports of yellowfin tuna or products thereof from any nation that could not certify that it had not in the preceding six months imported such products from a state subject to the direct embargo in the creating an extra territorial jurisdiction. The second panel focused more on Article XX ( $\mathrm{g}$ ), which addressed the "conservation of exhaustible natural resources". However, the outcome was the same. The panel held that the United States import prohibitions did not meet the requirements of Article III (National Treatment) and was contrary to Article XI (1) and were not covered by any of the exceptions in Article XX. Though Tuna/Dolphin I \& II were held in favour of the multilateral trading system, they remain a classical representation of the challenges that CSR can bring to international trade.

The WTO system is "rule based and represents the agreements negotiated by governments". ${ }^{89}$ In contrast, CSR codes of conduct are

of rights and obligations between the right of a Member to invoke one or another of the exceptions of Article XX, specified in paragraph (a) to (j), on the one hand, and the substantive rights of other Members under the GATT 1994, on the other hand. Exercise by one Member of its rights to invoke an exception, such as Article XX(g), if abused or misused, will, to that extent, erode or render naught the substantive treaty rights, for example, Article X1:1, of other Members". United States - Import Prohibition of Certain Shriom Products Appellate Body Report and Panel Report pursuant to Article 21.5 of the DSU Action by the Dispute Settlement Body. 4.

88 EEC and Netherlands v US (Tuna/Dolphin II) GATT Doc. DS29/R (16 January 1994).

89 See Understanding the WTO: The Agreements. Available at $<$ http//: www.wto.org/English/thewto_e/whatis_e/agrm1_e.htm $>$ Accessed 5 October 2019. 
voluntary and construed by private organizations to regulate the methods of participants in the supply chain. Multinational enterprises have sought to independently link trade agreements and voluntary CSR initiatives that incorporate policies that can protect human rights, employment, preserve the environment, provide information and consumer interest without direct national mandates..$^{90}$ While policy makers from Member States may want to do more to encourage businesses to act responsibly in countries where governance is weak, WTO Members cannot officially promote global CSR through the WTO agreements.

The WTO Secretariat has identified the dichotomy of these CSR requirements when it stated that:

Where a small number of retailers account for a high proportion of sales, the options for suppliers who do not participate in either an individual or collective retailer scheme can be considerably reduced. Furthermore, the retailer scheme may be de facto applied as the industry norm by all actors in the supply chain. Thus, the choice of whether or not to comply with a voluntary standard becomes a choice between compliance or exit from the market. In this way, the distinction between private voluntary standards and mandatory "official" or "public" requirements can blur. ${ }^{91}$

\subsection{Technical Barriers to Trade Agreement (TBT)}

To further the objective of GATT 1994, members recognized the importance of international standards and conformity assessment systems in the conduct of trade. ${ }^{92}$ This was the regulatory scope of the agreement on Technical Barriers to Trade (TBT).$^{93}$ This agreement is thought to bring in some form of flexibility in the conduct of trade between member states as well ensuring that members do not escape responsibility. The TBT

90 Tom Fox, Halina Ward and Bruce Howard, Public Sector Roles in Strengthening Corporate Social Responsibility: A Baseline Study (Washington, D.C.: World Bank, 2002).

91 Private Standards and the SPS Agreement: Note by the Secretariat, Committee on Sanitary and Phytosanitary Measures, 24 January 2007, G/SPS/GEN/746, para 4. Cited in Christian Vidal-Leon. Ibid, p. 913.

92 See the full TBT Agreement Available at < https://www.wto.org/english/ docs_e/legal_e/legal_e/17-tbt_e.htm> . Accessed 15 October 2019.

93 This is an agreement annexed to the Uruguay Round of Multilateral Trade Negotiations to further the objective of GATT 1994. 
Agreement contains disciplines for three different measures, namely, Technical Regulations (TRs); Standards; and Conformity Assessment Procedures (CAPS). Standards form the basis of TRs, ${ }^{94}$ and CAPS are procedures to check compliance with TRs ${ }^{95}$ Thus, the preamble to the TBT agreement states that:

Recognizing that no country should be prevented from taking measures necessary to ensure the quality of its exports, or for the protection of human, animal or plant life or health, of the environment, or for the prevention of deceptive practices, at the levels it considers appropriate, subject to the requirement that they are not applied in a manner which would constitute a means of arbitrary or unjustifiable discrimination between countries where the same conditions prevail or a disguised restriction on international trade, and are otherwise in accordance with the provisions of the Agreement.

The architects of the TBT Agreement were also concerned with traderestrictive TRs by local governments and non-governmental bodies by incorporating the "best effort clause" to ensure that members comply with the basic obligations of the WTO.

Article 2 provides that:

Members shall ensure that in respect of technical regulations, products imported from the territory of any Member shall be accorded treatment no less favourable than that accorded to like products of national origin and to like products originating in any other country.

Article 3 provides that:

Members shall take such reasonable measures as may be available to them to ensure compliance by such bodies with the provision of Article 2, with the exception of the obligation to notify as referred to in paragraphs 9.2 and 10.1 of Article 2 .

94 See Annex 1 to the TBT Agreement which defines it as a "document approved by a recognized body, that provides, for common and repeated use, rules and guidelines" ... Annex 3E provides that the "standardizing body shall ensure that standards are not prepared, adopted or applied with a view to, or with the effect of, creating unnecessary obstacles to international trade".

95 Annex 1.3 defines CAP as any procedure used, directly or indirectly to determine the relevant requirement in technical regulations or standards are fulfilled. 
It can be discerned that the "best effort" clause tries to strike a balance by granting WTO members some flexibility in imposing technical regulations, whilst ensuring on the other hand that they do not escape responsibility by virtue of Article $2 .{ }^{96}$ This means that such TRs may not constitute trade barriers. Thus, if a Member State takes reasonable measures, it would not be in violation of any trade restrictions. The burden is lessened by virtue of the "best effort" clause in Article 3. If a Member State takes such reasonable measures and yet a TR of a nongovernmental body does not comply with Article 2, the resulting inconsistencies would not engage the responsibility of the Member concerned. Conversely, if a Member State does not take such reasonable measures, it would be responsible for the inconsistences of a TR of a nongovernmental body with Article 2 of the TBT Agreement. The rule of responsibility under Article 3 simply means WTO members will only be responsible for non-observance Article 2 of non-governmental bodies where reasonable measures were not adopted. What comprises a nongovernmental body has been subjected to several interpretations. However, the agreement provides an incongruous definition that does not categorize what should constitute a non-governmental body but is rather general.

Annex 1.8 of the TBT defines it as:

a body other than the central government body or a local government body with powers to enforce a technical regulation.

After a careful analysis of the TBT agreement, it now becomes essential to ascertain if CSR codes of conduct constitute a TR. Can it be argued for all intents that members of the WTO had gone beyond the liberal market rule to now incorporate CSR as a way of creating efficiency in production through the TBT agreement? This question, by no means, produces a straight answer but may rather be controversial.

A technical regulation under Annex 1.1 is defined as:

A document which lays down product characteristics or their related processes and production methods, including the applicable administrative provisions, with which compliance is mandatory. It may also include or deal exclusively with terminology, symbols, packaging, marking or labelling

96 Ludvine Tamiotti, "Article 3 TBT" in Rudiger Wolfrum (ed) WTO - Technical Barriers and SPS Measures (Leiden/Boston: Martinus Nijhoff Publishers, 2007). 
requirements as they apply to a product, process or production method.

First, a technical regulation is mandatory, while on the other hand CSR are mainly voluntary initiatives. This is by no means dispositive of whether CSR are TRs as many multinational companies require suppliers to comply with CSR requirements or exit the market. Most firms have adhered to these initiatives through commercial contracts that require suppliers to comply with these codes. Secondly, a CSR code of conduct requires the use of certain labels and processes to show that certain standards and conformity assessment procedures have been complied with in the production of goods i.e. the Fair Trade Mark; Proudly South African Label, Certified Sustainable Palm Oil, RainForest Alliance Certified, Salmon Safe, Ecogeek, Ecological Footprint among other labels are examples of terminology, symbols, packaging, marking or labelling requirements within the framework of Annex 1.1. of the TBT agreement. Another example of related processes and production methods (PPM) will be the use of illegal child labour in garment factories or farms or the rights of indigenous communities where factories operate within Annex 1.1. However, this simplified analysis by no way settles the characterization of CSR codes of conduct as TRs.

The EC Seal Products ${ }^{97}$ are compelling given the interplay of the GATT objective and the TBT agreement which may come across as an exception to derogate from the multilateral trading principle. In this case, Norway requested consultations with the European Communities on trade in seal products and subsequent related measures (the "EC seal regime"). According to Norway, the EC seal regime prohibits the importation and sale of processed and unprocessed seal products, while unfair exceptions where granted to the EU market to Seal originating in the EC and certain developing countries, except Norway. Norway claimed that these measures were inconsistent with the obligations under Articles I.1(Most-Favoured Nation Treatment); Article III.4 (national treatment) and XI.1 (General Elimination of Quantitative Restriction) of the GATT and Articles 2.1 and 2.2 of the TBT Agreement. The panel held as follows: first, it was determined that the EU seal regime, as a technical regulation, did not violate Article 2.2 of the TBT Agreement because it fulfilled the

97 European Communities - Measures Prohibiting the Importation and Marketing of Seal Products. DS401 (18 June 2014). 
objective of addressing EU public moral concerns on seal welfare to a certain extent and no alternative measure was demonstrated to make an equivalent or greater contribution to the fulfilment of the objective. ${ }^{98}$ Secondly, it conceded that the EU seal regime violated Article I.1 GATT because an advantage was granted by the EU to seal products originating in Greenland and not accorded immediately and unconditionally to the like products originating in Norway. Third, with respect to the Marine Resource Management exception, the panel found that it violated Article III.4 GATT because it accorded imported seal products treatment less favourable than that accorded to like domestic seal products. Thus, the exceptions could not be justified under Article XX(a) of the GATT because they failed to meet the requirements under the chapeau of Article XX and also not justified under Article XX(b) GATT.

However, on appeal the Appellate Body reversed the Panel's finding, saying that the EU seals regime was a technical regulation within the meaning of Annex 1.1 to the TBT agreement and gave no legal effect to Article 2 of the TBT agreement. This was because the panel failed in applying the legal test to the chapeau of Article XX. Specifically, the Appellate Body reversed the Panel's findings that the EU Seal Regime laid down "product characteristics" within the meaning of Annex 1.1. The Appellate Body also upheld the Panels conclusion that the EU Seal Regime was inconsistent with Article I.1 of the GATT because it did not immediately and unconditionally extend the same market advantage to Norwegian seal products originating from Greenland and unjustified under XX of the GATT 1994. ${ }^{99}$

The Tuna Dolphin I/II and the EC Seals cases have beneficially accessed how certain quantitative restrictions may substantially affect internationally traded products, restrain market access and competitive

98 The concerns of the welfare of the Seals can be categorized under the exception of Article XX (a) GATT. This case can be distinguished from Thailand - Customs and Fiscal Measures on Cigarettes from the Philippines. where the appellate panel held that Article XX could not be raised because even though the ban on cigarettes was to protect a social value, i.e. health, there where alternative measures to be utilized by Thailand as opposed to an outright import ban. The Chapeau of Article XX is a condition precedent for the application of the exceptions. The chapeau also applies to the TBT agreement. See Thailand Customs and Fiscal Measures on Cigarettes from the Philippines.

99 The full facts of the case can be found on World Trade Organization. Available at https://www.wto.org/english/tratop_e/dispu_e/cases_e/ds401_ehtm. Accessed 11 July 2020. 
opportunities. Regardless of the necessity of these restrictions, meeting the chapeau requirement of Article XX has a high threshold especially when there are alternative measures to these restrictions. ${ }^{100}$ However, the Tuna/Dolphin I and II cases may have easily passed in favour of arguments for societal values over economic objectives, but they still remain controversial even in contemporary CSR discourse. Conversely, an evident dichotomy that would permit the trade bias is an argument that wealthy states like the United States can afford sophisticated fishing techniques while developing countries have limited affordability to develop such technologies which limit their ability to compete; hence the need to preserve the multi-lateral trading system. ${ }^{101}$ What can be easily discerned in these cases is that restrictions do exist and can be identified as a "legalization of the voluntary practice"102 which can override the WTO affirmative obligations and come under the Article XX exceptions if it meets the chapeau requirement. Thus, if developing countries cannot still meet these social restrictions then they would either need to comply or exist the market. ${ }^{103}$

\section{IMPLICATIONS FOR NIGERIA}

The Nigerian economy revolves around the oil and gas sector which has wielded, over the past five decades, a strong influence on the economy as a key revenue earner. Export of these commodities is the main factor behind Nigeria's growth and accounts for more than 91 per cent of exports. ${ }^{104}$ Prior to the oil boom of the 1970s, Nigeria was also largely agrarian and thus able to produce enough food to feed her growing population and export. Export crops were the country's main foreign exchange earner. For instance, the country was number one globally in palm oil exports and accounted for 18 per cent of the global production of cocoa. ${ }^{105}$

100 See Thailand - Customs (n 97).

101 UNCTAD (n 32).

102 ILO 2016 (n 29).

103 After the GATT decision, the tuna-dolphin dispute was resolved by agreements negotiated between the United States and the affected countries that called for Dolphin protection measures through a multilateral declaration on the importance of dolphin conservation.

104 See Nigeria-Exports - Trading Economics < https://tradingeconomics.com/ nigeria/exports $>$. Accessed 25 April 2019.

105 Adam, R. Green "Agriculture is the Future of Nigeria" Forbes (Africa, 8 August 2013) < http:www.forbes.com/sites/skollworldforum/2013/08/08/ 
Currently, Nigeria's key exports are crude petroleum, petroleum gas, cocoa beans, and rough wood. ${ }^{106}$ And its key imports are refined petroleum, passenger and cargo ships, wheat, cars, and raw sugar. Other notable imports are rice, palm oil, packaged medicaments, telephones, rubber tyres and motorcycles. ${ }^{107}$ The observatory for economic complexity (OEC) rates Nigeria as the 49th largest economy in the world and 124th most complex economy out of 126 countries. Nigeria's total exports could only account for US $\$ 46.8$ billion (to include crude petroleum and petroleum gas) worth of exports in 2017 with its top import origin from China. This is in stark contrast to Vietnam which grosses US\$204 billion annually, given that this was a country technically at war in 1989 but now exports broadcasting equipment, telephones, integrated circuits, textiles, leather footwear, electrical parts, and knitted fabrics. ${ }^{108}$

Nigeria is a country that has not properly integrated itself with the global economy, its export base has not diversified beyond oil. In 2005, the crop with highest production value was yams with a value of US\$8.71billion. ${ }^{109}$ This instigated the federal government to implement exportation of yams to Europe and United States as part of the move to diversify from oil. Unfortunately, 72 tonnes of yam that left the shores of Nigeria were rejected as the yams were found to be disintegrating upon arrival in the United States. ${ }^{110}$ This is in addition to the ban from the European Union (EU) in 2016 on 67 other processed and semi-processed food products of Nigerian origin, including brown beans, white beans, melon seeds, palm oil, mushrooms, bitter leaves, pumpkin leaves, shelled groundnut, smoked catfish and crayfish. All these were rejected because

agriculture-is-the-future-of-nigeria/amp/> accessed 27 July 2019. About 500 solid minerals have been discovered in 500 locations in the country. This includes large reserves of Natural gas, petroleum, tin, iron ore, coal, gold, limestone, niobium, lead and zinc. See also Alison D. Madueke, "Opportunities in Nigerian Mineral Sector" (Ministry of Mines and Steel Development, Nigeria April 2009).

106. Ibid.

107 Available at <http://atlas.media.mit.edu/e/profile/country/nga/>. See also https://commodity.com/nigeria/ Accessed 30 July 2019.

108 See the Observation of Economic Complexity. Available at < https://oec.world/ en/profile/country/vnm/> . Accessed 30th July 2019.

109 Available online < https/dataafrica.io/profile/Nigeria\#CropsByProduction $>$ Accessed 30th July 2019.

110 Steve Agbota, "Sad Story of Nigeria's Yam Export to America" (The Sun, 9 October 2017) < https//www.sunnewsonline.com/sad-story-of-nigerias-yamexport-to-america/> Accessed 30 July 2019. 
high levels of toxic chemicals and fungicides banned in foreign markets were used to preserve them. ${ }^{111}$

In contrast, Ghana accounts for 94 per cent of the total yam exports in West Africa and covers markets in USA, Canada, UK, and Europe. Furthermore, Ghana developed the National Yam Development Strategy and Yam Export Strategy aimed at increasing export volumes from 35,000 metric tonnes to as high as 400,000 metric tonnes. ${ }^{112}$ Ghana has adopted an agro commodity export dynamic, such as implementing new guidelines for yam export, thus making all yams for export to pass through a "singlecorridor" pack house that ensures adequate quality control by way of cleaning, packaging, sealing and labelling with a bar code, and electronic scanning. Also, Ghana has implemented yam export regulations to protect Ghanaian farmers and exporters and set up improved quality control agencies to prevent the use of yam exports for nefarious activities. For instance, Ghana's yam export trade employs over 1 million work force. ${ }^{113}$

For Nigeria to gain comparative advantage in international trade, the country must not only leverage on its domestic commodities but ensure its export base meets international standards and increase its knowledge base on agro-commodity export dynamics. The WTO does not expressly adopt CSR in international trade; yet, CSR has overwhelmingly formed a new paradigm in the way trade is conducted between private businesses. Developing countries like Nigeria should not regard CSR as a trade barrier and agencies and private producers responsible for agricultural produce must re-educate themselves as well as farmers to act responsibly and provide for an effective policy framework that ensures quality controls, reduction in the use of child labour, infrastructure for the preservation and storage of agricultural produce and a trading system that includes a commitment to global CSR. This would enable Nigeria to meet the UN Sustainable Development Goals in this regard, particularly Goals 1, 8 and 12 (poverty elevation, economic growth and responsible consumption and production, respectively).

111 See "EU ban: expert pushes for restricted pesticides use" (The Nation 7 September 2018) < https://www.thenationonlineng.net/eu-ban-expertpushes-for-restricted-pestcides-use/amp/> Accessed 3rd August 2019.

112 See "Ghana becomes first country to launch national yam strategy" (IITA, 14 October 2013) < https://www.iita.org/news-item/ghana-becomes-firstcountry-launch-national-yam-strategy/> Accessed 3 August 2019.

113 Ibid. 
Recently, the Nigerian Export Promotion Council advised cocoa farmers "on the need to properly ferment their cocoa beans to achieve better production and gain acceptance in the world market". ${ }^{114}$ Nigeria needs to improve its production, processing, packaging and marketing of non-oil export commodities in order to integrate with the global economy and gain competitive advantage which would otherwise significantly increase the nation's GDP.

However, the complexities occasioned by the onerous global reporting standards to include the codes of conduct and certification strategies imposed by private businesses cannot be over-emphasized as developing countries are finding it almost impossible to comply with these global standards. Thus, there is a wide gap in the joint implementation of CSR. There is a collective responsibility for all countries to meet SDGs by 2030, thus global CSR standards must be equitable and inclusive to ensure that developing economies can adapt to these requirements to eliminate decoupling. There is need to provide mutual supportive and technical assistance by way of capacity building through development cooperation to developing countries, particularly SMEs on adapting to international CSR standards to include disclosure and reporting, certifications, codes of conduct and eco-labelling for developing countries to better integrate into the multilateral trading system.

\section{CONCLUSION}

The discourse on CSR is a complex one, as can be seen in its various definitional perspectives which provide divergent forms of interpretations of what CSR requires. Similarly, the voluntary nature of CSR has placed suppliers in developing countries under the pretext that CSR codes of conduct are restrictive which arguably inhibits the aspirations of the "multilateral trading system". However, the reality is that private businesses that implement these codes expect suppliers and multinationals alike to subscribe to global reporting and disclosure initiatives such as the GRI, ISO standards and certifications strategies which have become mainstream for continued business relations to ensure transparency and accountability in production standards. Thus, countries that cannot adapt to CSR requirements are highly likely to exit the market.

114 See "Why Nigeria's cocoa can't compete in global market". Punch online: Available at Punchng.com. Accessed 30 August 2019. 
CSR goes beyond the requirements of the WTO as CSR is a voluntary initiative conducted by private businesses and operating outside the purview of the WTO mandate. Linking CSR to WTO can be herculean as such links may distort the "multilateral trading system". Businesses, including small and medium enterprises especially from developing countries, must understand that there is a business case for CSR that can implement heterogeneous CSR strategies in order to compete favourably in the global market.

Nigeria has a large population that is totally severed from the global economy. To compete in global trade, it is important to incorporate CSR as this will increase competitiveness, significantly increase the country's GDP as well as create jobs. When an industry expands the demand for manpower rises, thus eradicating poverty and improving the livelihoods of its citizens and thus meeting the Sustainable Development Goals by 2030 . 